\title{
GENERAL EDITOR'S INTRODUCTION
}

The historiography of imperialism is staggeringly rich and, just as importantly, it continues to show signs of repeatedly reinventing itself. One of the most productive phases in this process has been the work surrounding the concept of the 'British World' (and its variant, the British World System), which stimulated a whole succession of conferences and publications, mainly in the twenty-first century. This book, focusing on questions of migration, makes a notable contribution to this on-going debate. The conference at which these papers were first delivered, held in Bristol in 2007, was a strikingly lively affair, and some of that vibrancy comes through here. For a start, the extensive introduction by the two editors forms an exceptionally valuable survey of the idea of the 'British World' and the manner in which it can be applied to many forms of migration, embracing territories of settlement, so-called 'dependent' colonies, areas often known as 'informal empire', as well as the ways in which such global movement became far more transnational and indeed less 'British' in modern times. All of this not only pulls together the themes of the papers with great skill, but implicitly indicates fresh directions for research. It should indeed constitute a starting point for all students wishing to acquaint themselves with this field.

Meanwhile, the papers themselves strike out in a variety of new directions. They cover such fields as migration in relation to nineteenth-century demographic theory, various aspects of religious and missionary dispersal, producing tensions between forms of nationalism and Christian universality, the presence or absence of imperial sentiment in the minds of migrants, as well as non-white migration in the form of the extensive movement of Asian people in the second half of the nineteenth century and the early years of the twentieth. The invariably forced migration of children has been much written about and has stimulated forms of apology in recent years. Here we have a significant case study which casts fresh light on these often disturbing processes. We also hear of the plight of single female emigrants and the conditions they endured in Canada in the 1920s, as exposed by a public-spirited member of the Imperial Order Daughters of the Empire. Yet another case study relates to a cache of correspondence, illustrating the means whereby migrants maintained connections with 'home', transmitting news of the circumstances in which they found themselves and their attempts to familiarise the unfamiliar. In addi- 


\section{GENERAL EDITOR'S INTRODUCTION}

tion, we have several papers on the decolonisation era, less well covered in past studies of migration. In African territories where Europeans had settled, independence created new dilemmas, notably whether to 'stay on' or not. There is much to be written about this and the chapter on Zambia should stimulate other studies. In recent decades, we have new forms of cosmopolitan migration and 'sojourning' as well as continuing questions of integration and multiculturalism in countries like Britain and France which have experienced major migrations from their former empires. These two significant fields are covered in the last two chapters.

Thirty years ago, the distinguished historian of science and of the environment, Roy MacLeod, substituted the notion of the 'moving metropolis' for simplistic dispersal theories in respect to the spread of western scientific notions. The 'moving metropolis' idea fits the British World well, in at least two respects. The conferences themselves took place not just in Britain, but also in Australia, New Zealand, Canada and South Africa (as it happens almost mirroring the moving conferences of the British Association for the Advancement of Science in the early twentieth century). But beyond that it is apparent that the British World concept embraces many forms of territorial, demographic, and cultural pluralism, as well as ideas about networks within a web of intra-colonial connections, and transnationalism moving from imperial to global contexts. Moreover, the British World idea showed itself capable of providing a framework for those connections among economic and social, religious and intellectual, environmental and cultural histories that became part of the historians' quest from the 1980s onwards.

The question arises where do we go from here? There will of course continue to be a place for national histories, but the emerging studies (some in this series) that compare the experience of different territories mainly within the British Empire need to be encouraged and extended. But my answers to the question of future directions go beyond this and are entirely personal: I think we need more work that moves across the borders of different empires, perhaps even in chronological as well as geographical terms. In other words, we need to think in much more comparative terms about empires in general and parallel forms of modern imperialism in particular. We also need to recognise that white people can be divided up into different ethnicities as much as indigenous peoples in Asia, Africa and elsewhere. It is for this reason that I have been promoting the concept of a 'four nations' approach to the history of the British Empire, in pursuit of what may be termed Irish, Scottish, English and Welsh Worlds. Each of these ethnicities had distinctive social, cultural, religious and intellectual forms to offer 


\section{GENERAL EDITOR'S INTRODUCTION}

to empire and the world. As always, the 'Studies in Imperialism' series will set out to be in the forefront of both the comparative and the four nations approaches, while responding, of course, to the many other suggestions that may emerge.

John M. MacKenzie 